\title{
Chapter 10 \\ Governing Migrants and Refugees in Hungary: Politics of Spectacle, Negligence and Solidarity in a Securitising State
}

\author{
Céline Cantat
}

\subsection{An Invitation to the Hungarian Border Spectacle ${ }^{1}$}

One early morning in July 2016, I travelled to Szeged with a colleague to meet with one of the organisers of Migszol, the local pro-refugee movement. Tamas ${ }^{2}$ had offered to drive us to the border crossing point in Röszke where, in the autumn of 2015, the Hungarian government had established one of the transit zones in which migrants wishing to enter Hungary are systematically detained as they go through the asylum process. We drove through open fields of paprika stretching to the horizon and reached a bumpy road going through a small forest. At the end of the path, we arrived at the border: if it had not been for the barbed wire fence cutting through the grass, I would never have guessed that this was where Hungary stopped and Serbia commenced. There it was: 'the zone'. In the middle of the otherwise deserted countryside, a set of containers surrounded by a wire fence stood incongruously, presenting us with a somewhat surreal scene. After a few kilometres of emptiness, we had suddenly reached a site of intense activity: the Hungarian army and the police were busy surveying the transit zone where fewer than a dozen people had been admitted from the Serbian side that same morning. They were now waiting to hear whether or not they would be allowed into Hungary. A couple of children were running around, looking and smiling at us from behind the wire. On the Serbian side, a makeshift camp of tents and tarpaulins had emerged, as more people arrived on a daily basis than the number let through the transit zone. Tamas told us that the

\footnotetext{
${ }^{1}$ An earlier version of this chapter was published by the CEU Center for Policy Studies (CPS) as a Working Paper (2017/3).

${ }^{2}$ All names have been changed for reasons of anonymity.

C. Cantat $(\bowtie)$

Central European University, Budapest, Hungary

e-mail: cantatc@ceu.edu
} 
camp had recently reached 600 people and that numbers were expected to keep rising. People were camping at the border crossing point, with no access to cooking or proper hygiene facilities, in the hope of being able to cross into Hungary soon. Around the tents, humanitarian workers and volunteers wearing colourful variations of the same vest were busy distributing water or carrying out medical checks. Some of the police on the Hungarian side were staring blankly at the migrants and their humanitarian supporters across the wire.

'Look', said Tamas, 'this is what they have done here. You can take photos if you wish, but do not photograph Hungarian military or police staff'. Since the summer of 2015, Tamas had been relentlessly working to support migrants passing through Szeged and to document the situation at the border. He had brought numerous journalists and researchers to the Röszke transit zone and had played an important role in allowing the media to gain information about the Hungarian government's treatment of refugees. Yet something felt wrong. Not only did I not feel comfortable getting my camera out to take photos of people stranded in such dreadful conditions but the simple fact of being there and gazing at the scene seemed improper. We walked a few metres along the barbed wire border and reached a small hill at the top of which two men were smoking a cigarette. One of them was a member of the military who had been sent to Röszke from Western Hungary, where he usually lived with his family, to reinforce border surveillance operations. However, in the few months that he had been there, he had never caught sight of a single migrant trying to cross irregularly. He just spent his days standing on top of a small hill, looking at the Serbian fields extending ahead.

It struck me that the scene had been carefully staged. Each person at the transit zone had a clear role to play in a scenario with a simple yet efficient plot: the state had sent national servants to defend the border and the nation against the disruption and menace represented by the migrants. It had its protagonists and its villains. There was a desirable order of things which had been brought into crisis by the movement of unwanted people and which had to be protected. Like other researchers, activists and journalists, I also had a role in this script - I may have felt little sympathy towards the narrative, yet I was part of the public that made the spectacle possible. The Röszke transit zone told a particular story, with its own morals, in which the Hungarian national community was in need of protection and the state was the protector. The production of refugee vulnerability and muteness is central for this staging to proceed: as silenced subjects, refugees can be attributed whichever role is the most convenient to the government's narrative. As such, the narrative requires two simultaneous operations: the systematic silencing of refugees through processes of vulnerabilisation taking away the possibility of self-expression, coupled with the hyper-visibilisation of their vulnerabilised presence.

This was what felt wrong: the simple fact of attending the show, of providing it with a public, made me complicit in this obscene border spectacle. The concept of 'spectacle' has been usefully mobilised by critical migration and border studies scholars to refer to dominant representations surrounding migration and their instrumental role in the consolidation of statist and territorialised politics. De Genova (2015) speaks of the 'border spectacle' in reference to the way in which states stage 
dramatic scenes of enforcement at/of the border. This, of course, has a purpose: that of displaying the power of the state to enforce the politics of exclusion and control on which national authority and sovereignty rely. Rajaram (2003) also examines the 'spectacle of detention' of asylum-seekers in the Australian context and argues that such a performance is designed for a public, identified and cohered through the consumption of such a spectacle and that it hence plays a central role in the drawing of the moral and ethical limits of the political community.

This visit to the Röszke transit zone stayed with me as I continued researching migration and pro-migrant solidarity in Hungary over the next few months. The uncomfortable feeling of being an unwilling accomplice in the production of a narrative about a 'migrant threat' or a 'migration crisis' in the country was as powerful as it was paralytic. The issue bore some questions: what was the Hungarian government attempting to achieve through this hyper-visibilisation of borders and migration? Moreover, besides what it tried to show, what did this spectacular moment also relegate to less visible spaces? What else was quietly happening backstage as the public's attention was focused on the show? What other practices of exclusion and 'disintegration' might be employed by the Hungarian authorities?

In this chapter, I reflect on the politics of in/visibility that underpin the government of migrants and refugees by the Hungarian authorities. I explore how an ongoing process of disintegration of the already narrow social, political and economic space navigated by migrants and refugees in the country is produced through both spectacular practices of marginalisation and quiet forms of neglect. Unlike 'exclusion', which implies the casting out of particular individuals and groups from an already established community, the notion of (dis)integration insists on the dialectical relation between, on the one hand, preventing the emergence of socialities that bring together, in this instance, 'nationals' and 'non nationals' and, on the other hand, the reinforcement and indeed integration of a particular, and highly exclusionary, interpretation of the 'nation' and the legitimate public (Collyer et al. 2020).

I first examine the various spectacularisation practices deployed by the Hungarian state and reflect on the representations of migrants, migration and the Hungarian national community that the government puts forward. I then look at what may be called 'the other side' of the migration spectacle - that is, the more discreet yet equally corrosive practices that become quietly authorised and banalised in this context. The final part offers some reflections on the effects of this double politics of hyper-visibilisation and quiet neglect in regard to the social space available to migrants in Hungary. I argue that one of the intended consequences of this politics of visibility is to sap the conditions allowing the emergence of alternative communities and ways of being together beyond racialised differences. I also examine examples of pro-migrant mobilisation in Hungary to assess whether and how these can, even temporarily, subvert the conditions created through the spectacularisation of migration. Due in particular to the largely transitory nature of migration in/through Hungary in 2015, the focus of the chapter is primarily on the way in which Hungarian citizens attempt to challenge the politics of difference and separation enforced by the government in relation to migration as well as to other social processes. 


\subsection{Reinforcing the National Community and Its Others}

At the end of November 2016, still in Szeged, the local district court gave a Syrian man known as Ahmed H. a 10-year prison sentence on charges of 'illegal entry' and 'acts of terror'. The acts behind these charges dated from 16 September 2015, a day after Hungary closed its borders to migrants and refugees on their way to Western and Northern European countries. Hundreds of walkers, stranded at the Röszke/Horgoš crossing, where the transit zone mentioned above currently stands, attempted to break through the border fence that had been erected by the Hungarian authorities. The response of the police consisted in the brutal use of force, including tear gas and water cannons, to contain people. Ahmed seized a megaphone to try to call on both refugees and the police to remain calm. As clashes intensified, Ahmed was involved in stone throwing, together with dozens of exhausted refugees. He was arrested in Budapest a couple of months later and held in detention until his trial. Ten other people present at the border that day were also arrested: they were put on trial over the summer of 2016 and received a range of actual and suspended sentences for illegal entry and public disorder. The fact that these people aimed to enter European territory in order to claim asylum which, under international conventions related to refugee protection, should protect them from charges of 'illegal entry' did not make a difference, a testimony to the Hungarian government's voluntary disqualification of all border crossers as 'illegal migrants'. Ahmed was heard separately due to the terrorist charges levelled on him, based on the argument that he had been involved in attempts to intimidate the Hungarian police.

These trials took place in March 2016, a few months after the Hungarian authorities had declared a 'state of emergency' across the country. The measure had officially been taken because of the 'migrant crisis', yet it was passed at a time when the number of people transiting through Hungary had drastically declined, due in particular to the barbed wire fences at the borders with Serbia and Croatia. In June of the same year, the government passed a draconian counter-terrorism package, which included a constitutional amendment ${ }^{3}$ and changes to the laws governing the police, national security services and defence forces. The aim of the package was to simplify the process to establish a state of emergency in the country and to grant the executive stronger 'counter-terrorism' powers, with wide scope for restricting rights and increasing surveillance. The package also established Hungary's new CounterTerrorism Intelligence and Criminal Analysis Centre (TIBEK). In the name of protecting the national community against an imagined migrant threat, the Hungarian government has thus justified a series of repressive and restrictive laws with consequences for all residents.

The passing of this so-called 'anti-terrorism' package is, to a certain extent, in line with developments at the European level, notably since the Paris and Brussels attacks. Yet it is also an element of Hungary's ruling party Fidesz's political strategy

\footnotetext{
${ }^{3}$ To Magyarország Alaptörvénye, the Fundamental Law of Hungary.
} 
(Fidesz or Magyar Polgári Szövetség means 'Hungarian Civic Alliance'). Since the spring of 2015, the 'safety of Hungarian citizens' has emerged as a key issue in the public and political debate. Fidesz has deployed a range of tactics aimed at asserting a connection between migration and migrants on the one hand and the destabilisation of public order and terrorism on the other. An important element of this strategy was the 2 October 2016 referendum calling for people to vote against the EU's mechanism of refugee relocation. The campaign leading up to the referendum was overwhelmingly focused on affirming a link between migration and terrorism, with billboards across the country displaying messages such as 'Did you know that the Paris attacks were carried out by migrants?' or the distribution of a booklet to over four million Hungarian households containing sentences such as 'Illegal immigration increases the threat of terror'. Previously, in April/May 2015, the government had orchestrated a 'national consultation', as a part of which virtually all Hungarian households received a questionnaire featuring 'leading questions' of a xenophobic ('Do you agree with the Hungarian government that, instead of supporting immigrants, the support of Hungarian families and future babies is needed?') and nationalistically anti-EU ('Would you support the Hungarian government in the introduction of stricter immigration laws as opposed to the permissive policies of Brussels?') nature (Migszol 2015). These moves have been instrumental to Fidesz in order to maintain its levels of support in spite of corruption scandals, protests from various social groups (including teachers and workers) and growing dissatisfaction from segments of the population due to the concentration of power and the long-term rule of the party. In this context, 'security' issues remained one of the key arguments used by Fidesz to attract voters in advance of the spring 2018 parliamentary election. PM Orbán, in fact, claimed that migration was 'the Number One issue' of the election, which would determine whether or not Hungary became an 'immigration country' (Daily News Hungary 2018).

Appealing to a fabricated need to secure the nation against the migrant Other has become a key tool of power for the Hungarian government. This process has been recently furthered by the introduction of a legislative package soberly entitled 'Stop Soros', which criminalises a wide range of activities in support of asylum-seekers (including legal and material assistance) and has been presented as a 'national security' measure by the Hungarian government (Cabinet Office of the Prime Minister 2018). The new laws render extremely difficult the work of a number of local and international organisations concerned with the respect of human and migrants' rights. In this sense, the securitisation of migration is a process with broader implications for the country and one that participates in the alienation of parts of its society and civil sector. In other words, beside the production of disintegrating conditions for migrants and refugees, discourses against migration have had a farreaching disintegration effect in the country as a whole.

Ahmed's trial was a particularly striking example of 'the border spectacle'. It produced a moment of hyper-visibility of both illegalised migration - thereby acting as confirmation of the Hungarian government's discourse of crisis and threat - and of the authority of the state to enforce exclusion, thereby affirming its ability to provide 'safety' for the Hungarian public against an imagined menace. The specta- 
cle portrays a national community whose primary concern consists in the control of 'illegal' migration. It also works to invisibilise the very processes through which this illegality is produced. As noted by De Genova, while some migrants are deemed 'illegal' because they have violated the law, 'in most depictions of these migrants, there is little if any account of what the law truly is, or of how it came to be so" (De Genova 2015). Yet the law has a history. This history is deeply politicised: it reflects a particular reading of reality, which, in most cases, echoes the interests of the powerful. Migrants become illegal when legislative arrangements make certain forms of mobility illegal - in other words, illegalise them. In the Hungarian case, the criminalisation of so-called illegal entry is a recent phenomenon, dating back to September 2015 as part of a series of measures aimed at terminating the so-called migration crisis. Ahmed, and the ten other people arrested and sent to trial alongside him, were all made illegal by recent Hungarian legislative measures which, in turn, provided the state with the perfect scene for the demonstration of its ability to enforce the law, punish those who break it and exclude those deemed as illegitimate.

Those who lack the means to impact on or contest the making of the law and of legality and illegality - among which migrants feature prominently alongside other marginalised groups - typically become irresistible targets over whom states exercise and demonstrate their authority. Structural silencing makes such vulnerable groups ideologically profitable canvasses on which state power can be projected and displayed. This is not unique to Hungary: the 'migrant' has emerged as a key image of otherness globally and states around the world have mobilised this figure of threat to justify security-oriented and authoritarian measures (Cantat 2015). These restrictive measures are often aimed at neutralising domestic social and political tensions and discontent, including those emerging from the mutation of the local state into a manager of global neoliberal capital. At times, this also translates into disagreements regarding the way to approach migration management across different levels of government (see Desille 2020; Hinger 2020).

The borders at which this 'spectacle' has been unfolding are not only the Hungarian borders; they also are the external borders of the European Union (EU), of which Hungary has become a 'guard' in the context of the Europeanisation of immigration control (Cantat 2015). While Hungary has been at times pilloried for its ill-treatment of migrants by other European leaders (Euractiv 2015), it is worth highlighting that the process of border securitisation in the country has been actively encouraged and supported financially by EU institutions. Indeed, since at least the mid-1990s and the harmonisation of migration policy at the European level, the increasingly deterritorialised and securitised borders of the EU have been a key location for the production of the forced migrant as a figure of fear (Cetti 2012). It is also important to note that the use of a rhetoric that mixes security and humanitarian concerns in order to justify further border control has also become a feature of the EU border regime at large (Vaughan-Williams 2015).

In Hungary, the most recent moves towards further securitisation and authoritarianism have been justified in relation both to this global figure of the migrant Other and in the name of preserving the country from 'outsiders' and particularly 'Muslims'. Yet the processes of militarisation, securitisation and criminalisation of 
Hungarian society, which have targeted primarily Hungary's minorities and poor, including Hungarian Roma and homeless people, must be located in longer-term dynamics. Since his arrival to power in 2010, Prime Minister Viktor Orbán has rewritten the constitution, curtailed the powers of the Constitutional Court, eroded welfare in favour of an enforced workfare targeting primarily Roma and the poor (Szöke 2015) and actively participated in the establishment of an environment within which racist speech and supposedly prohibited far-right paramilitary activities are tolerated, particularly in the villages where the Roma live (Fekete 2016). These developments constitute a redrawing along increasingly discriminatory lines of the boundaries of the legitimate public - a form of 'exclusionary integration' that works in a dialectic relation with attempts at disintegrating alternative spaces and discourses. This must also be analysed in the framework of the so-called Europeanisation of Hungary and Central Europe which has unfolded in the context of a brutal transition from communism to capitalism (from a command economy to a market economy) under the auspices of the World Bank and the IMF. This transition paved the way and indeed was a prerequisite to Hungary entering the EU in 2004. In the next part, I examine how the production of the migrant as a new figure of fear in Hungary has translated into what I call practices of 'banal marginalisation'.

\subsection{Quiet Neglect and Banal Marginalisation}

The spectacularisation of migration and of border confrontation is thus a process with important implications. Not only does it allow the reassertion of the legitimacy and authority of the state and the conjuring up of a particular image of the national community, it also enables a process of blame displacement. This reorients the popular discontent and hostility triggered by economic and political difficulties towards those produced as illegitimate in the narratives underpinning border spectacles. This process, which manifests itself at national and regional levels, is a global phenomenon, which has worked toward the emergence of the migrant as a global figure of unwanted Otherness (Cetti 2012; Cantat 2015).

Arguably, there is a paradox in migrants and refugees being simultaneously produced as not belonging to and outside the realm of the (nationalised) economy and politics and yet as responsible for the ills of contemporary societies. This is perhaps particularly striking in Central and Eastern European member-states of the EU, where political discourses towards migration are characterised by extreme levels of violence, while the numbers of people actually obtaining asylum and residency (and thus living in these countries) are actually very low. ${ }^{4}$ The inconsistency of this

\footnotetext{
${ }^{4}$ According to statistics produced by the Hungarian Helsinki Committee, in 2016 only 154 people were granted asylum status, while 271 people received subsidiary protection and seven humanitarian protection. Moreover, according to amendments made in June 2016 to the Hungarian legislation concerned with international protection, people who received protection have to review their
} 
double discourse seems, however, to go unnoticed. This is in large part rendered possible through the structural vulnerabilisation and silencing of migrants and refugees, who are systematically denied access to means of political expression. In turn, this has direct consequences on the space available to people produced as both outsiders to the social, political and economic order and as responsible for its erosion or disintegration.

An important way in which this can be illustrated is by reflecting on the way in which the border spectacle staged by the state allows and legitimises a range of racialising and othering practices against migrants and refugees. The hypervisibilised events to which I referred in the first part of this chapter are only one side of the story. The other side of this mediatised discourse, and its more discreet continuity, is the way in which a series of measures of neglect and destitution becomes authorised and normalised.

In the Hungarian context, such examples of active negligence and the violence they entail are plentiful. Some of the most shocking examples illustrate powerfully the extent to which dehumanising representations may in turn authorise inhuman treatment. In the winter of 2016, the Hungarian government quietly closed Bicske camp, one of the oldest open reception camps for asylum-seekers. While such open asylum detention facilities are far from desirable, what came to replace Bicske proved to be even worse. Indeed, as an alternative, the government displaced Bicske residents to containers or tent camps close to the borders of the country. This episode took place quite discreetly, in the heart of a draconian winter with temperatures reaching $-20^{\circ}$. People found themselves isolated from their previous connections, including those they had established in Budapest - where many of the pro-migrant associations are based and activities of the country take place - and in conditions barely suitable for human beings. A few months later, in April 2017, the Hungarian government decided to stop providing food to asylum-seekers detained in one of the reception camps, which primarily hosts people going through an asylum appeal process. This series of destitution measures was adopted about a year after the Hungarian government drastically reduced support to asylum-seekers (who are simultaneously prevented from working) and cut all benefits specific to refugees on the grounds that there should be no differential treatment compared to Hungarian people.

Acts of everyday destitution - including, among others, the longevity of asylum procedures and the fact that migrants are often implicitly encouraged to leave the country and to continue their travel westward - are also visible in practices of quiet brutality exercised against asylum-seekers in the camps. These practices differ from the hyper-visible spectacle in that they are either unacknowledged or are quite often framed in administrative rather than political terms. They are about the routine and banal way in which mistreatment, neglect and marginalisation are organised, enacted and reinforced.

status every 3 years - essentially meaning that even those granted refugee status only benefit from a three-year secured residency permit. 
The neglect here is thus not of a benign form. It may amount to forms of physical violence or torture being inflicted onto the bodies of people, yet it is activated through a deliberate lack of care rather than through acts of violence. In spite of a tendency to frame this in terms of administrative efficiency (or the lack thereof in the case of long asylum processes), this neglect is political. It is not the mere result of a lack of resources or structural conditions - it is politicised insofar as it is imposed on particular people or groups of people in particular ways. Here, it is articulated through the production of the figure of the migrant as one of national threat, which relies on a dehumanising set of practices and discourses that not only justifies but fully banalises extreme forms of mistreatment towards migrants.

In the next part, I assess the consequences of this double politics of hypervisibilisation and quiet neglect on the social space available to migrants in Hungary. I argue that, beyond the immediate experience of brutality and its many consequences on people's lives, these discourses, images and practices also have a perhaps less visible but equally pernicious effect. Indeed, they attempt to sap the conditions allowing the emergence of communities based on alternative socialities between Hungarians and migrants, and of ways of being together beyond racialised differences. Against this context, however, I present two solidarity initiatives that have emerged in support of migrants in the country and examine their structure and meaning in the context of the Hungarian 'border spectacle'.

\subsection{Migrant Solidarity in Szeged and Pécs}

Another expression of the politics of neglect and (dis)integration enacted actively by the Hungarian government, as elsewhere in Europe, has been the criminalisation of a range of acts of solidarity - or their framing as smuggling. When, albeit under restrictive conditions, spaces of relative autonomy and self-organisation - forms of what I call 'vernacular integration', that is, popular practices by citizens and noncitizens that produce social, political and economic relational and/or productive spaces regardless (often in spite) of state's policies - have arisen, they have been systematically dismantled. This is partly how we could understand the closure of the Bicske camp, which had been a space where social relations between residents, both past and current, had developed and around which a certain number of activities were emerging. The disintegration process imposed on migrants in Hungary thus consists in ongoing attempts to prevent the emergence of links with a national public that the government simultaneously tries to define and delineate as it spectacularises exclusion and its putative protection of the national community.

This hypothesis might be particularly true in the light of the mass mobilisation in support of people on the move in the summer of 2015. Despite active government campaigns against migrants, involving billboards and a national consultation since spring 2015, impressive numbers of people throughout the country came out in support of those who attempted to travel through Hungary and found themselves stranded in various sites due to the government's strategy of migrant immobilisation. 
Some of the most poignant images of the summer of 2015 perhaps are those of hundreds of volunteers and activists supporting migrants in some of Budapest's central parks and stations. Yet this wave of solidarity extended beyond the more visible Budapest-based mobilisation and also emerged in other cities of the country, primarily those located close to the borders.

I now turn to the examples of two Hungarian border cities that were the stages of relatively significant pro-migrant movements in the summer of 2015 and examine the relation between these solidarity initiatives and official representations of migration and of the national community deployed by the government.

Over the course of the summer of 2015, over 100,000 people transited through Szeged, next to the Serbian border, while up to 5000 people passed through Pécs, close to the border with Croatia. These border cities constituted some of the first places that refugees encountered as they entered the country. Refugees who passed through Pécs were driven by the Hungarian police from other border towns to the city's train station for reasons that remain unclear. Once fingerprinted and provided with a registration number, they were set free in the city with no information as to how to continue their journey. While some claim that people were relocated to Pécs in order to decongest other cities (in particular Szeged), volunteers from Migszol Pécs considered this to be a deliberate, orchestrated move on the part of the Hungarian authorities which, they claim, aimed to provoke hostility towards migrants and refugees by having large numbers of unassisted migrants in the streets of Pécs. In response, however, a significant number of people came together to provide assistance to those on the move, including overseeing transportation to Budapest and coordinating with groups operating there, as well as providing food, clothing and medical support when necessary.

In both places, refugees would just be arriving into Hungary and trying to make their way to Budapest, where they hoped to board a train that would take them to Austria, Germany and beyond. They would be lacking food, water, sometimes clothes and medication as well as, importantly, information. While, as I will comment on below, the local authorities in Szeged and Pécs differed in their approach to the situation of refugees, in both contexts there was no organised and systematic effort by them or by the national authorities to either assist people locally or facilitate the continuation of their journey. In both cases, a group of local residents came together under the name of Migszol (respectively Migszol Szeged and Migzsol Pécs) in order to 'fill the gap' left by the lack of intervention on the part of the local and national authorities. The number of volunteers involved on a regular basis in Migszol Szeged was about 150 people, while the core group of Migszol Pécs consisted of around 40-50 volunteers. Pro-migrant activities in Szeged were, to some extent, facilitated by the local authorities, which provided a storage and distribution place in the form of a wooden cabin located next to the station where the majority of Migzsol activities were taking place. This was possible insofar as Szeged is distinctive in the Hungarian context and has a Socialist mayor who stands as a declared 
opponent of governmental party Fidesz. In Pécs, the local authorities did not provide any form of support to the civilian group and their rapport was extremely tense.

What were these groups' politics and how did they relate to governmental discourses regarding migration and the Hungarian 'national community'? Speaking with representatives of both groups quickly indicated an insistence on presenting their initiatives as apolitical and driven purely by humanitarian and solidarity concerns. In particular, they showed strong defiance towards any form of party politics, as the following two anecdotes illustrate. During a group interview on 16 June 2016, two of the key coordinators of Migszol Szeged told us:

Interviewee 1: At some point, we had the opportunity to get a donation from the European Socialists. A large amount. (...)

Interviewee 2: Seven million HUF. That is a really big sum, not something you flush down the drain (...).

Interviewee 1: It was a very big dilemma. If it had just been a truck of mineral water, we could have said 'No' easily, but this is such a sum ... So we talked (with other groups) and we said that, if they get out in the media that we get money from the Socialists... (pause) so we said 'Thanks' and recommended giving the money to the Greeks. We don't want to receive money from any political organisation.

In Pécs, the initiator of Migszol explained not only how the local Socialist party had helped them by providing a small storage room and some tents but also how he was worried that this would affect the reputation of Migszol Pécs. One volunteer commented, in an interview on 16 July 2016, on how this was dealt with by the coordinators of Migszol:

One of the tents ... clearly belonged to the Socialist party because it had the flower on it the emblem of the Hungarian Socialist Party. And A. and the leaders of this little camp, they were always telling us to put that tent on the bar inside out, so as not to show that this belongs to the Socialist Party, because this is not a political venture, this is not a political activity. They were trying to make it as apolitical as possible.

This distancing from party politics, sometimes framed as a reluctance to be political in general, is not unique to the initiatives under consideration. The so-called democratic transition of Hungary has been marked by forms of political and economic instability that often resulted in strong popular disillusion with political parties. Between 1990 and 2002, Hungary saw three different governing coalitions. At the end of each term, the vote swung in the opposite direction. The pattern was interrupted in 2006 with the re-election of the Hungarian Socialist Party but, only a few months after the elections, the uncovering of the Party's alleged lies during the election campaign and of various corruption scandals led to a series of protests and to the repudiation of the government. Since 2010, the nationalist conservative party Fidesz has dominated the Hungarian political scene, leaving little room for opposition. In a context of increasing authoritarianism by the party in power, Fidesz, repeated disappointment with party politics sometimes seems to translate into a refusal to associate themselves with any political party by people engaging in social or oppositional activities. 
Yet, in spite of this insistence on distancing themselves from any political party and specific political identity as a group, interviews with the key people (initiators and coordinators) of both Migszol groups clearly showed that they held marked political opinions and that their activities have been shaped in particular by a conflicting relation to the Fidesz-led Hungarian government. In addition to their genuine objection to the mistreatment of people on the move by the Hungarian authorities, the Migszol groups' involvement was influenced and structured by a broader and longer-term opposition to the Hungarian authorities and the social, economic and political relational modalities they encourage. Hence, while insisting on the civilian, non-political nature of the overall group, many individual volunteers were moved by anti-government positions and imaginations of a different society and alternative modes of sociality in Hungary. In other words, these groups actively rejected the (dis)integrating practices of the authorities, refusing to 'integrate' into a fully exclusionary imagination of the national body and rather enacting a form of popular or vernacular integration by engaging with people deemed Others in official discourses.

\subsection{Recovering the Politics}

The core group who established Migszol Szeged and coordinated its activities throughout the summer was composed of long-term acquaintances with relatively well-known positions as socially engaged people in the city. For years, they had run a local alternative radio station, which had to shut down following the Hungarian government's passing of restrictive broadcasting laws in 2010 (CMCS n.d.). In previous years, they had been key organisers of a number of protests, including the Internet tax protest and the teachers' strike. Volunteers to whom I spoke in Szeged had often been in contact with them prior to the summer of 2015 and their credibility as socially engaged and reliable people was central to bringing people into Migszol Szeged and building relationships of trust.

Experience of previous joint actions and struggles was also key to the establishment of Migszol Pécs. Again, the group was consolidated by previous encounters and relationships. One of its central members whom I met in Pécs declared that she had been involved in workers' struggles and trade unionism for the last four decades. At a time when large numbers of migrants passed through Pécs, she was able to solicit support from the local police union, with whom Migszol could establish a functional working relationship, at least at the beginning. The local police would let Migszol volunteers know every time new people were brought into the city, allowing the group to organise support accordingly. The core Migszol group had also been heavily involved in defending other cohorts of people marginalised and illegalised by the Hungarian authorities. A few years ago, as in other Hungarian municipalities, Mayor Zsolt Pava criminalised homelessness in Pécs. This provoked outrage among some of the local residents, who quickly organised a group to coordinate support for the homeless and poor of the city. The group has been organising 
food and clothes distribution, as well as solidarity events such as Christmas celebrations, and many group members have been key figures in Migszol Pécs. Here, again, common opposition to the government and local authorities, a shared understanding and rejection of the process through which vulnerable groups are targeted, and previous experience of collective protest, were central to building the initiatives that emerged over the summer.

This is important for several reasons. First, it allows a more complex reading of the solidarity initiatives that took place in favour of migrants in the summer of 2015, on which there has been precious little research in Hungary. ${ }^{5}$ In what has been published, scholars have, at times, deemed the forms of volunteerism that emerged in Hungary in 2015 as limited or apolitical (Kallius et al. 2016). I suggest that looking at the case of Szeged and Pécs can both challenge and complement such analysis in important ways. It can help us to develop a better understanding of pro-refugee solidarity in Hungary and encourages us to exercise caution when criticising support initiatives towards refugees by deeming them forms of humanitarian or charitable volunteerism with no political awareness.

In both cities, opposition to Fidesz and its attempts to capitalise on the suffering of migrants and other vulnerable groups for political purposes and for promoting a particular idea of the national public, were repetitively referred to as key motives for involvement. This conflicting - and, to an extent, dialectical - relationship to Fidesz preceded the so-called migrant 'crisis'. It had been built up over many years in opposition to the multiple ways in which the Hungarian government has produced internal and external enemies with the aim of stabilising its power and creating a climate of social fear and a disintegration of social ties that do not fit into the official narration of the Hungarian 'nation'. It is therefore not coincidental that many of the interviewees recounted that they had previously assisted other vulnerable groups. These latter include, prominently, the Roma, as the national figure of internal Otherness whom Viktor Orbán has relentlessly evoked over the last few years as a counterpoint to his vision of an ordered and desirable Hungarian public. However, it also extends to groups - such as the elderly, the disabled, the poor and the homeless - who have been vulnerabilised in various ways through the neoliberal transition in Hungary. The connection between these conditions and struggles was most forcefully advanced by one of the coordinators of Migszol Pécs, who said:

I hold Viktor Orbán responsible for the death of my mother. She had cancer, and had her leg and breast amputated. They operated on her and after the operation ... they threw her out on the street... Now it is the same thing with my wife: she had a serious brain operation and they have taken away her 'pension for disabled people'. We got into such a serious situation, by the way, that officially I am now homeless. I don't have a flat... But even with all of these events, we have to keep doing things, because there are people who are in the same boat as

\footnotetext{
${ }^{5}$ Though limited, scholarly attention has been paid to pro-migrant initiatives in Hungary, including to volunteers' motivations for engaging in support activities and the effects of 'helping encounters' on their understanding of migration (Feischmidt and Zakaria 2016). Questions regarding the tensions and contradictions between the different humanitarian and solidarity actors active in Budapest in 2015 have also been raised (Kallius et al. 2016). However, up to now little research has been conducted on pro-migrant solidarity in the Hungarian context beyond the city of Budapest.
} 
us and we try to help them. I can give the example of how, on a daily basis, they push the homeless out of the city centre. They can't even be there. The police harass them (Interview 18 July 2016).

The connections recognised between the different forms of marginalisation and inequality in this excerpt sketch out forms of identity and solidarity that go beyond charity and humanitarianism. They speak to the recognition of shared material conditions and of comparable positions in the face of the state and of capital. The forms of exclusion referred to here concern the violent discursive and physical segregation faced by migrants and refugees, as much as forms of economic relegation leading to situations of poverty, hardship and exploitation. This also highlights forms of belonging that could work towards the expansion of the space available to migrants so that they can form connections to other groups in the country. In other words, against a process of marginalisation and alienation of certain social groups orchestrated by the Hungarian government, the volunteers in this research engage in actions which one could call 'acts of integration' (see Collyer et al. 2020) or, as proposed, of 'vernacular integration'.

This must also be assessed in light of the history of the city of Pécs. As explained, Pécs was an old industrial and mining centre which experienced the brutal closure of it industries and mines over the last two to three decades, followed by a brief period of foreign investment that has largely come to a halt, leading to high levels of unemployment and social misery. The interviewee previously quoted explained that he came from a working-class family of 14 children, marked by poverty and economic hardship. He positioned himself in material terms and articulated a discourse close to a class positioning that frames and makes intelligible the actions he carries out in solidarity with various groups, including, but not restricted to, refugees. For instance, at the end of my first day of fieldwork in Pécs in July 2016, a number of Migszol Pécs volunteers explained that they were driving to deliver clothes and food to impoverished Roma communities living in villages around Pécs.

Activists who made up the core group of Migszol Szeged came from somewhat different class positions. They were mostly university-educated people working in higher education or non-governmental organisations. The motivation they put forward for engaging in solidarity initiatives towards refugees was not about the sharing of material conditions, yet they also articulated ideas of a common struggle in opposition to the vision of society and of the national community imposed by the Hungarian government. One of the key organisers of the movement explained in an interview on 17 July 2016:

This is not only about supporting people in need, this is about the sort of people we want to be, the sort of countries we want to live in, the sort of social relations we want to imagine. We do not want this narrow nationalism, we never did; ever since Orbán has come up with this way of speaking of Hungary and its history I have fought against it.

Here again, the position articulated is one of solidarity, where concepts of reciprocity and commonality are strongly emphasised. The interviewee mentions motivation that may be understood as humanitarian ('supporting people in need') yet he frames such concerns in a way that insists on the mutual interests embedded in pro-refugee 
actions, in the sense that supporting refugees and migrants is also about producing integrated socialities that reflect more closely his vision of a desirable society. He understands these initiatives as part of a larger struggle against particular political visions of Hungarian society that were mobilised to justify the mistreatment of refugees in the summer of 2015 and beyond, but that also existed before and were previously employed by the Hungarian authorities to redraw the boundaries of the national community along narrow socio-cultural lines and to target vulnerable groups.

I would like to argue that it is precisely because such political positionings and reflections existed before the arrival of refugees and migrants in Hungary that largescale initiatives could be promptly established in cities like Szeged and Pécs. A number of the volunteers who participated in this research understood their promigrant stance as a moral and political necessity in relation to the broader context of authoritarianism in Hungary. While the forms of morality involved might have underlying humanitarian tones, they were also articulated politically. Volunteers' and activists' actions were triggered by a wider outrage towards the national and local authorities' ongoing criminalisation and Othering of different groups. In other words, these were forms of opposition to the official dialectics of (dis)integration that attempts to prevent socialities with those identified as not belonging to the nation. They were, at times, sustained by powerful forms of identification with the circumstances faced by people on the move.

\subsection{Conclusion}

As seen, the Hungarian state has deployed a series of mechanisms and measures aimed at marginalising refugees and migrants, and at preventing their integration within Hungarian society and socialities. This process relies on the production of a legitimate and desirable Hungarian public, which excludes not only migrants but also a number of citizens and civil organisations engaged in supporting those framed as Others in the dominant national narrative put forward by the Hungarian authorities. The related disintegration of certain socialities and reinforcement of a particular image of the nation can be usefully conceptualised through the notion of (dis) integration, which forces us to reflect on the dialectic between the integration of certain social groups and the prevention of others from entering the symbolic, discursive but also social and political space of national belonging. The shift to a securitising and authoritarian mode of government in the country has led to both a spectacular rise in xenophobic discourses and practices and to a narrowing of the public sphere underpinning a process of alienation and an experience of disintegration for an increasing number of members of Hungarian society.

In spite of and against this repressive environment, a series of pro-migrant initiatives emerged in the country throughout 2015. This chapter has focused more particularly on the cases of Migszol Szeged and Migszol Pécs, two independent civil initiatives in support of and solidarity with migrants and refugees that were estab- 
lished at the borders with Serbia and Croatia respectively. As seen, volunteers engaged in Migszol groups often refer to their activities in terms that would be broadly understood as humanitarian. This chapter, however, shows that their work has a political dimension, especially thanks to the long-term involvement of core volunteers in both Migszol Szeged and Migszol Pécs in practices of mutual support and solidarity that challenge not only the discourses of crisis and exceptionalism deployed in relation to the mobilities of summer 2015 but also the ongoing process of nation-building along various exclusionary lines deployed by the Hungarian authorities.

Since the 'crisis' was terminated through the deployment of aggressive bordering strategies, some of the Migszol volunteers in both Szeged and Pécs have remained socially and politically active or have resumed their previous activities. In Szeged, the initiators of Migszol have been key in allowing the monitoring and documentation of the situation at the border and in particular at the Röszke transit zone. Some of them have changed career to become involved as professional aid workers with local or international NGOs. In Pécs, Migszol members are continuing their activities in support of the homeless and poor people from the city and neighbouring villages. They have also been providing support to the Roma inhabitants of nearby towns.

In conclusion, despite difficult circumstances and the ongoing closure of spaces where solidarity can be practiced, these initiatives keep rejecting the restrictive representations of a moralised Hungarian public and start imagining alternative communities. In so doing, they enact acts of integration that directly challenge the official discourses of belonging of the Hungarian government.

\section{References}

Cabinet Office of the Prime Minister. (2018, February 21). 'Stop Soros' legislative package is an important step. Retrieved May 5, 2018, from http://www.kormany.hu/en/news/ stop-soros-legislative-package-is-an-important-step

Cantat, C. (2015). The ideology or Europeanism and Europe's migrant other. International Socialism Journal, 152. Retrieved May 5, 2018, from http://isj.org.uk/ the-ideology-of-europeanism-and-europes-migrant-other

Cetti, F. (2012). 'Europeanity', the 'other' and the discourse of fear: The centrality of the forced migrant as 'global alien' to an emerging European national identity. Unpublished $\mathrm{PhD}$ thesis, University of East London, London.

CMCS. (n.d.). Public service media. Retrieved May 5, 2018, from http://medialaws.ceu.hu/public_service_media_more.html

Collyer, M., Hinger, S., \& Schweitzer, R. (2020). Politics of (dis)integration - An introduction. In S. Hinger \& R. Schweitzer (Eds.), Politics of (dis)integration (pp. 1-18). Cham: Springer VS.

Daily News Hungary. (2018, March 26). Election 2018 - Orbán: Migration number one issue. Daily News Hungary. Retrieved May 5, 2018, from https://dailynewshungary.com/ election-2018-orban-migration-number-one-issue/

De Genova, N. (2015, May 20). The border spectacle of migrant 'victimisation'. Open Democracy. Retrieved May 5, 2018, from https://www.opendemocracy.net/beyondslavery/ nicholas-de-genova/border-spectacle-of-migrant-\%E2\%80\%98victimisation \%E2\%80\%99 
Desille, A. (2020). Jewish immigrants in Israel: Disintegration within integration? In S. Hinger \& R. Schweitzer (Eds.), Politics of (dis)integration (pp. 141-159). Cham: Springer VS.

Euractiv. (2015, August 31). Fabius calls Eastern Europe's reluctance to receive migrants 'scandalous'. Euractiv. Retrieved May 5, 2018, from https://www.euractiv.com/section/ justice-home-affairs/news/fabius-calls-eastern-europe-s-reluctance-to-receive-migrantsscandalous/

Feischmidt, M. \& Zakaria, I. (2016, November 17-18). Identity-based politics and solidarity beyond and across borders. Case study on Hungarian civic activists effected by refugees. Budapest: Central European University, paper given to a workshop entitled Challenging the political beyond and across borders.

Fekete, L. (2016). Hungary: Power, punishment and the 'Christian-national idea'. Race and Class, $57(4), 39-53$.

Hinger, S. (2020). Integration through disintegration? The distinction between deserving and undeserving refugees in national and local integration policies in Germany. In S. Hinger, R. Schweitzer, Politics of (dis)integration (pp. 19-39). Cham: Springer VS.

Kallius, A., Monterescu, D., \& Rajaram, P. K. (2016). Immobilizing mobility: Border ethnography, illiberal democracy, and the politics of the 'refugee crisis' in Hungary. American Ethnologist, $43(1), 25-37$.

Migszol. (2015, May 5). Fidesz's 'National Consultation' is no consultation at all. It is a shameless piece of propaganda - A Migszol commentary. Retrieved May 5, 2018, from http://www. migszol.com/blog/fideszs-national-consultation-is-no-consultation-at-all-it-is-a-shamelesspiece-of-propaganda-a-migszol-commentary

Rajaram, P. K. (2003). The spectacle of detention: Theatre, poetry and imagery in the context over identity, security and responsibility in contemporary Australia (Asia Research Institute Working Paper No. 7). Singapore: National University of Singapore. Retrieved May 5, 2018, from http://www.ari.nus.edu.sg/wps/wps03_007.pdf

Sözke, A. (2015). A 'road to work'? The reworking of deservedness, social citizenship and public work programmes in rural Hungary. Citizenship Studies, 19(6-7), 734-750.

Vaughan-Williams, N. (2015). Europe's border crisis. Biopolitical security and beyond. Oxford: Oxford University Press.

Open Access This chapter is licensed under the terms of the Creative Commons Attribution 4.0 International License (http://creativecommons.org/licenses/by/4.0/), which permits use, sharing, adaptation, distribution and reproduction in any medium or format, as long as you give appropriate credit to the original author(s) and the source, provide a link to the Creative Commons licence and indicate if changes were made.

The images or other third party material in this chapter are included in the chapter's Creative Commons licence, unless indicated otherwise in a credit line to the material. If material is not included in the chapter's Creative Commons licence and your intended use is not permitted by statutory regulation or exceeds the permitted use, you will need to obtain permission directly from the copyright holder.

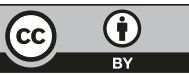

